\title{
EDITORIAL
}

\section{CONGRESO INTERNACIONAL DE TELECOMUNICACIONES}

El Congreso Internacional de Telecomunicaciones, SENACITEL, se ha realizado cada dos años desde 1984, habiéndose consolidado como un importante espacio del sector de las telecomunicaciones, con la participación de ingenieros, académicos y especialistas de universidades nacionales y extranjeras, además del sector empresarial y de gobierno.

El comité editorial del Congreso, integrado por destacados académicos de universidades nacionales y extranjeras, junto a investigadores de nivel nacional e internacional, ha velado con dedicación y rigurosidad por la calidad de los temas seleccionados.

La alianza entre el Congreso Internacional de Telecomunicaciones SENACITEL 2004 y la Revista de la Facultad de Ingeniería-Universidad de Tarapacá abre un nuevo espacio que permite a cada investigador de la problemática de telecomunicaciones entregar la información pertinente, de manera que sus pares puedan evaluar y valorar los procesos intelectuales que la originaron.

La oportunidad que nos ofrece el convenio con la Revista de la Facultad de Ingeniería-Universidad de Tarapacá, una publicación SciELO CHILE, que se enmarca dentro de las políticas de CONICYT de fomento de la investigación y la difusión de sus resultados, dota de un nuevo valor a los trabajos presentados al Congreso, en cuanto es la comunidad científica y tecnológica, junto a especialistas en telecomunicaciones, las que juzgan y valoran las presentaciones, dando fe de la calidad de los trabajos seleccionados.

En este sentido, la Revista de la Facultad de Ingeniería-Universidad de Tarapacá es un medio que constituye un aporte de excelencia al conocimiento y a las experiencias de la investigación, y a través de su publicación pone al alcance de ingenieros, estudiantes y académicos información y bibliografía de primer nivel profesional en el campo de las telecomunicaciones.

La comunicación, divulgación y difusión de materiales informativos, evaluados en forma rigurosa por los comités de la Revista de la Facultad de Ingeniería-Universidad de Tarapacá y SENACITEL, generan confianza y dan un valor agregado a los temas presentados en los congresos de SENACITEL.

Pedro Rey Clericus Presidente

SENACITEL 2004

Valdivia, Chile
Néstor Fierro Morineaud

Presidente Comité Editorial

SENACITEL 2004

Valdivia, Chile 
EDITORIAL

\section{INTERNATIONAL CONFERENCE OF TELECOMMUNICATIONS}

Since 1984 The SENACITEL International Conference has been held every other year, with the participation of engineers, faculty and specialists from Chilean and foreign universities, as well as representativas of the Chilean government and the private sector. Presently, after twenty years of uninterrupted meetings, the Conference has been established as an important event in the field of telecommunications.

The Conference Editorial Board, among whose members there are high ranking faculty from Chilean and foreign Univesities, as well as high level scholars, has always rigorously screened paper proposals.

The alliance between the 2004 SENACITEL International Conference and the Revista de la Facultad de IngenieríaUniversidad de Tarapacá represents a new opportunity for scholars in the area of telecommunications, for sharing scientific information and assessing the intellectual processes that originate new knowledge.

The agreement between the SENACITEL International Conference and Revista de la Facultad de Ingeniería-Universidad de Tarapacá, a SciELO indexed journal that complies with the policies of CONICYT, the Chilean Commission for Scientific and Technological Development, brings an added value to the papers presented at the conference, as the scientific community, as well as, the specialists in telecommunications evaluate the proposals and ultimately select the works for presentation.

The Revista de la Facultad de Ingeniería-Universidad de Tarapacá is a sound contribution to knowledge and research, its articles offering first hand information and bibliography to faculty, engineers and students. The quality of the information presented at SENACITEL conferences is therefore guaranteed by the rigorous selection of manuscripts by the SENACITEL International Conference and the Revista de la Facultad de Ingeniería-Universidad de Tarapacá editorial boards.

Pedro Rey Clericus

President

SENACITEL 2004

Valdivia, Chile
Néstor Fierro Morineaud

President Editorial Committee

SENACITEL 2004

Valdivia, Chile 